\title{
Los vencedores (derrotados) de la Guerra Civil: falangistas en el cine. Imaginario y representación
}

\section{The (Defeated) Winners of the Civil War: The Falangists. Imaginary and Representation}

\author{
IGOR BARRENETXEA MARAÑÓN \\ Universidad del País Vasco \\ ibm@euskalnet.net
}

\begin{abstract}
Resumen: Tras el fin de la Guerra Civil española se constituyó el Nuevo Estado. Las diferentes familias que habían concurrido en apoyar la causa de los militares sublevados contra la Segunda República constituyeron lo que se ha denominado franquismo. Y de entre estas familias victoriosas de la guerra cobró, sin duda, un inusitado protagonismo Falange, conocido como el Movimiento (a partir de 1937, Falange Española Tradicionalista y de las JONS, tras su unificación con los carlistas), que había pasado de ser un partido fascista minoritario a otro de masas en la posguerra. El triunfo militar les llevó a pretender imponer su ideario político a través de la cultura y los medios de comunicación. La representación de la guerra y del ideario de Falange en el cine nos va a mostrar, claramente, a través de una serie de filmes seleccionados que van desde Frente de Madrid - Carmen fra i rossi(1939) hasta La prima Angélica (1974), su escaso recorrido y su rápida derrota frente al conservadurismo del régimen franquista. Así que la Falange de José Antonio ganó la guerra pero perdió la paz, se concentraría en ser la base social del franquismo (a través de la Sección Femenina), aunque despojado, en mayor medida, de todo lo que le hizo ser el primer partido fascista de España.
\end{abstract}

Palabras clave: Falange, franquismo, cine, memoria, historia.

\begin{abstract}
After the end of the Spanish Civil War, the New State was constituted. The different families which had concurred in supporting the cause of the rebelled militia against the Second Republic became what has been called Franco's regime. It is from those war victorious families that became, without a doubt, unusually prominent the Falange, known as "the Movement" (from 1937 as "Traditionalist Spanish Falange" and of the "JONS (Committee of the National-Syndicalist Offensive)", after its unification with the Carlists), which had turned from a minority fascist party to one of masses in the post-war period. The military triumph led them to try to impose their political ideology through culture and mass media. The representation of the war and the ideology of the Falange in the film industry is clearly going to show us its short life and its quick defeat
\end{abstract}

Recibido: 1 de noviembre de 2017; aceptado: 28 de diciembre de 2017; publicado: 27 de septiembre de 2018. Revista Historia Autónoma, 13 (2018), pp. 161-180

DOI: https://doi.org/10.15366/rha2018.13.009 
against the conservatism of Franco's regime, through a series of selected films arranging from Frente de Madrid - Carmen fra i rossi- (1940) to La prima Angélica (1974). José Antonio's Falange won the war but got lost in the peace; therefore, it would focus on being the social base of Franco's regime (through its feminine section), albeit divested of everything which made it the first Spanish fascist party.

Keywords: Falange, Franco's regime, cinema, memory, history. 
"La definición ideológica del régimen franquista no puede separarse del decreto de Unificación que creó Falange Española Tradicionalista y de las JONS, asumiendo como bagaje doctrinal e ideológico 26 de los 27 puntos programáticos falangistas. Otro momento crucial es la superposición del Caudillo, cabeza visible del Estado, con la figura de Jefe Nacional de Falange Española, el 31 de julio de 1939"'.

\section{Introducción}

El cine es una fuente inagotable de conocimiento para los historiadores. Es un documento en vivo del pasado pero a la vez de las sociedades representadas.

Por su capacidad de seducción e influencia, los totalitarismos y los regímenes autoritarios se dieron muy pronto cuenta de su importancia. Como espectáculo de masas no solo se exigía controlar sus discursos (de hecho, lo primero que hicieron los militares sublevados en la Guerra Civil española fue dictaminar las primeras medidas de censura $)^{2}$ sino que constituía la base de un proyecto político y social que, en mayor o menor medida, aspiraba a imponer una ideología. Se buscó "educar" (y controlar) a la sociedad y para eso se emplearía el cine como un esencial instrumento movilizador, adoctrinador y pedagógico ${ }^{3}$. Sin embargo, también sabemos que la propaganda cinematográfica no alcanzó a cumplir tales utópicos objetivos. El gran público buscaba entretenimiento, por lo que los largometrajes con un contenido excesivamente ideológico fallaron en imponerse y porque el rico y sutil lenguaje del cine pudo sortear la censura y mostrar otros aspectos críticos de la sociedad ${ }^{4}$.

Tal y como sintetizaban Ferro y Rosenstone, el cine puede construir una "historia oficial" del pasado o bien todo lo contrario, convertirse en un "contraanálisis" de la misma. Como agente de la historia provoca sentimientos y los instituye, ayuda a mitificar o desmitificar ideas y también construye, desde la metáfora, visiones de un pasado (críticas, falsas o idealizadas)

\footnotetext{
${ }^{1}$ Amador Carretero, Pilar, "La mujer es el mensaje. Los coros y las danzas de la Sección Femenina en Hispanoamérica", en Feminismo/s, 2 (2003), p. 102.

${ }^{2}$ Gubern, Román, La censura. Función política y ordenamiento jurídico bajo el franquismo (1936-1975), Barcelona, Península, 1981; Álvarez Berciano, Rosa y Ramón Sala Noguer, El cine en la zona nacional, 19361939, Bilbao, Mensajero, 2000; Diez Puertas, Emeterio, El montaje del franquismo, la política cinematográfica de las fuerzas sublevadas, Barcelona, Laertes, 2002.

${ }^{3}$ Camporesi, Valeria, Para grandes y chicos. Un cine para los españoles 1940-1990, Madrid, Ediciones Turfan, 1994; Sanz Ferreruela, Fernando, Catolicismo y cine en España (1936-1945), Zaragoza, Institución Fernando El Católico y Diputación de Zaragoza, 2013.

${ }^{4}$ Hueso, Ängel Luis, El cine y el siglo XX, Barcelona, Ariel Historia, 1998.
} 
que se vinculan a la sociedad a la que están dirigidas. De ahí que cobre tanta relevancia el imaginario audiovisual ${ }^{5}$.

Así, establecido el marco teórico de reflexión, en este artículo se pretende ahondar sobre cómo fue la representación de una de las familias que apoyaron a los militares sublevados en 1936: los falangistas. Aunque no pretendemos ser exhaustivos, hemos compilado una amplia base de películas, dejando a un lado los documentales, que nos ofrecen las claves a la hora de valorar como retrató el régimen, o permitió que lo hiciera la cinematografía nacional, a este "otro" compañero de viaje.

Los falangistas fueron una ideología "moderna", en términos de temporalidad histórica (no ideológica) defensora de un Estado corporativo y totalitario. Muy pronto se unió a la causa y enemigo común la Segunda República, a la que se culpó y responsabilizó de todos los males que arrastraba el país 6 . Como escribe Ángel Duarte, "la República no era otra cosa que el último hito en la deriva antinacional"'

Sin embargo, para vencer en la guerra, Franco, que se iba a convertir en el Caudillo de estas fuerzas, necesitaba la unidad de las familias y las corrientes que apostaron por la sublevación. Y así, para evitar rivalidades, aprobaría el Decreto del 19 de abril de 1937 en el que se estableció la unificación de carlistas y falangistas. En palabras de Cervera esto significó que, históricamente, "moría la Falange y nacía el franquismo". Porque, tal y como señala Richmond, "la decisión de Franco de fusionar la Falange con otros partidos de la derecha creó una base de poder para ganar la guerra" ". La guerra fue ganada pero no así la paz para estas familias del régimen que vieron sus proyectos derrotados, caso de Falange ${ }^{10}$. Y el cine va a ser muy revelador a este respecto, aunque se pueden constatar dos importantes etapas.

\section{Primera etapa (1939-1942)}

Falange de las JONS surgió en 1933, pero no dejó de ser un partido muy minoritario durante los años de la República. Gracias a su sólida estructura organizativa, constituida en

\footnotetext{
${ }^{5}$ Ferro, Marc, Historia contemporánea y cine, Barcelona, Ariel, 1995; Rosenstone, Robert, El pasado en imágenes, Barcelona, Ariel, 1997.

${ }^{6}$ Cazorla Sánchez, Antonio, Las políticas de la victoria, Madrid, Marcial Pons, 2000; Egido León, Ángeles (ed.), Memoria de la Segunda República. Mito y Realidad, Madrid, Biblioteca Nueva, 2006; Bullón de Mendoza, Alfonso y Luis Eduardo Togores (coords.), La República y la Guerra Civil. Setenta años después, Madrid, Actas, 2008; Cuesta, Josefina, La odisea de la memoria, Madrid, Alianza Editorial, 2008.

${ }^{7}$ Duarte, Ángel, "La República, o España liberada de sí misma”, en Moreno Luzón, Javier y Xosé Manoel Núñez Seixas (eds.), Ser españoles. Imaginarios nacionalistas en el siglo XX, Barcelona, RBA, 2013, p. 121.

${ }^{8}$ Cervera, Javier, Madrid en Guerra. La ciudad clandestina 1936-1939, Madrid, Alianza Editorial, 1998, p. 122.

${ }^{9}$ Richmond, Kathleen, Las mujeres en el fascismo español. La Sección Femenina de la Falange, 1934-1959, Madrid, Alianza Editorial, 2004, p. 23.

${ }^{10}$ Aunque, en realidad, Falange Española y de las JONS sería renombrada Falange Tradicionalista y de las JONS tras la unificación, me voy a referir a Falange de forma más genérica.
} 
esos años de clandestinidad y de violencia callejera, no solo había conseguido salir airosa de la prueba de fuego de la contienda sino que además se había acabado por convertir en un auténtico partido de masas. La vitola que había logrado con su "pistolerismo" y su apoyo a los militares sublevados dio lugar a que miles de jóvenes se adscribieran a sus filas. Acabada la guerra alcanzaría casi el millón de afiliados. Por ello, sin minusvalorar su importancia, el régimen de Franco asumió algunos de sus rituales y emblemas como el saludo fascista, el himno (Cara al sol) y utilizó la imagen de José Antonio, asesinado en Valencia, como emblema para constituir sus pilares. La influencia del fascismo, en pleno auge en la Europa de entreguerras, era notoria sobre todo tras el apoyo recibido en la guerra por la Alemania nazi y la Italia fascista ${ }^{11}$.

Pero si hubo algo que todavía cobró más relevancia en el tema que nos ocupa fue el hábil interés de la Falange por incautarse de las imprentas de los periódicos y medios de comunicación que cayeron en sus manos, tras la liquidación de los partidos políticos y ocupación de sus sedes, sabedores de la importancia que estos cobraban en la constitución de una "nueva" sociedad. Claro que el ideal de Franco, militar africanista, no era instaurar un régimen político al estilo alemán ni italiano sino utilizar el Movimiento Nacional (como se denominaría la fusión de falangistas y carlistas) para que lo ayudase a mantener la cohesión y el control de la población en un Estado de carácter corporativo militar. Por eso, el desarrollo de un proyecto falangista puro, en su momento de mayor influencia, nunca se daría. Mucho menos cuando Franco, sin José Antonio, no tenía a nadie que le disputase la primacía en el Nuevo Estado ${ }^{12}$.

Aun así, la historiografía distingue dos etapas esenciales: desde 1939 hasta 1942 como un periodo en el que la Falange tuvo una gran influencia en el régimen (momento de máximos triunfos militares de la Alemania de Hitler en la guerra mundial) y, a partir de 1942, cuando se consideró que la Falange fue totalmente "domesticada"13.

Esto iba a coincidir muy bien con la manera en la que la Falange o su ideario iban a ser plasmados en el cine de ficción.

En la primera etapa la influencia y control de Falange de ciertos instrumentos de propaganda y comunicación fueron muy significativos. La Delegación de Prensa y Propaganda (1937), el Departamento Nacional de Cinematografía (1938), la Subcomisión Reguladora de Cinematografía (1939), la Vicesecretaría de Educación Popular de FET y de las JONS (1941), de la que nació la Delegación Nacional de Cinematografía y Teatro y el Sindicato Nacional del Espectáculo (SNE), estarían bajo su dominio hasta que a partir de 1942 se iría sustrayendo

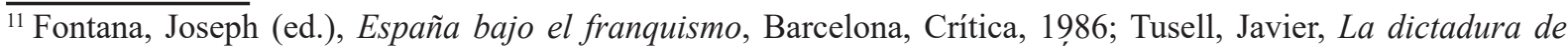
Franco, Madrid, Alianza Editorial, 1988; Gracia García, Jordi y Miguel Ángel Ruiz Carnicer, La España de Franco (1939-1975), Madrid, Síntesis, 2001; Juliá, Santos y Giuliana di Febo, El franquismo, Barcelona, Paidós, 2005; Box, Zira, España, año cero, Madrid, Alianza Editorial, 2010.

${ }^{12}$ Payne, Stanley G., Falange. Historia del fascismo español, Madrid, Sarpe, 1985, p. 202; Preston, Paul, Las tres Españas del 36, Barcelona, Plaza \& Janés, 1998, pp. 99-140.

${ }^{13}$ Payne, Stanley G., Falange.... op. cit., p. 203.
} 
ese control y delegándolo en el Ministerio de Educación Nacional, bajo la supervisión de los sectores católicos ${ }^{14}$.

Aparte de esto, la Junta Superior de Censura Cinematográfica (1937), integrada por falangistas, eclesiásticos y militares, que posteriormente se convertiría en Junta Superior de Orientación cinematográfica (1946), vería como el representante eclesiástico ostentaba el derecho a veto de aquellas películas inadecuadas de acuerdo a la moral católica ${ }^{15}$. En el momento álgido en el que la Falange fue quien marcó las principales directrices en su intento de construir un "cine nacional" (hasta 1942), estableció una serie de consignas encauzadas a través de la revista Primer Plano (1940) ${ }^{16}$. Sin embargo, a pesar de la retórica oficial a la hora de "renovar" el panorama cultural, lo cierto es que el ideal de la Falange nunca se pudo adueñar de la gran pantalla. Tanto es así que la catalogación de un cine propiamente falangista resulta una ardua tarea y no hay quórum entre los especialistas. Porque películas de identidad o características temáticas falangistas "puras" fueron una rareza.

Para la primera etapa triunfal, Marta Recalde considera falangistas aquellas películas cuyos aspectos religiosos son menos notorios y son afines a sus ideales ${ }^{17}$. Entre estas estarían ¡Harka! (1941), de Carlos Arévalo, o ¡A mí la legión! (1942), de Juan de Orduña, que mostrarían el sueño imperial falangista y que eran además sendas apologías militaristas ${ }^{18}$, así como la coproducción con Italia Sin novedad en el Alcázar (1940), de Augusto Genina, El crucero Baleares (1941), de Enrique del Campo, retirada forzosamente porque no fue del gusto de los militares, la versión de 1941 Raza, de José Luís Sáenz de Heredia y Porque te vi llorar (1941), de Juan de Orduña, hasta llegar, por supuesto, a Rojo y negro (1942), de Carlos Arévalo.

Si bien, aunque rodada en Italia, le faltaría señalar Frente de Madrid (1939), de Edgar Neville, por el hecho que es de las pocas películas en las que nos encontramos con un protagonismo claro de un joven falangista durante la guerra.

Para Recalde todas ellas enseñaban el "sacrificio, heroísmo y hermandad"19, afín al ideario de José Antonio, además de darse otras subtemáticas como el culto a los muertos, la redención ética, la presencia de un ideal femenino y un fuerte catolicismo.

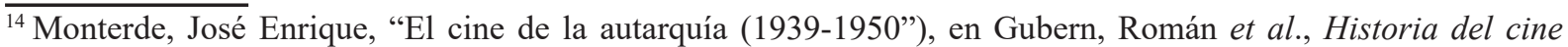
español, Madrid, Cátedra, 2015, p. 188.

${ }^{15}$ Gubern, Román, La censura ... op. cit., pp. 51-81; Monterde, José Enrique, “El cine...” op. cit., pp. 189-190.

${ }^{16}$ Ortego Martínez, Óscar, "Cine, realismo y propaganda falangista: un ejemplo en la revista Primer Plano", en Ruiz Carnicer, Miguel Ángel (coord.), Falange, las culturas políticas del fascismo en la España de Franco (19361975), vol. 2, Zaragoza, Institución Fernando el Católico, 2013, pp. 394-407; Castro de Paz, José Luis, Un cinema herido, Barcelona, Paidós, 2002, p. 24; Minguet i Batllori, Joan M., La regeneración del cine como hecho cultural durante el primer franquismo (Manuel Augusto García Viñolas y la etapa inicial de "Primer Plano”), Alicante, Biblioteca Virtual Miguel de Cervantes, 2000.

${ }^{17}$ Recalde Iglesias, Marta, "La lucha entre la Iglesia católica y Falange en el ámbito cinematográfico (1936-1945), en Huarte de San Juan. Geografia e Historia, 21 (2014), pp. 301-329.

${ }^{18}$ Bermejo Sánchez, Benito, "La Vicesecretaría de Educación Popular (1941-1945): un ministerio de la propaganda en manos de Falange", en Espacio, tiempo y forma. Serie V: Historia Contemporánea, 4 (1991), p. 88. Claro que, tras el desembarco de los aliados en las costas africanas, el régimen se encargó de intentar soslayar este aspecto expansionista ante el temor de interpretar mal sus intenciones y perder sus colonias; Viscarri, Dionisio, “¡Harka! Representación e imagen del africanismo fascista”, en Revista de Estudios Hispánicos, 12 (2002), pp. 403-424.

${ }^{19}$ Recalde Iglesias, Marta, "La lucha entre..." op. cit., p. 317.
} 
A este bloque cabría añadir, según Luis Fernández Colorado ${ }^{20}$, Fortunato (1941), de Fernando Delgado, documentalista del régimen durante la guerra, por sus características de crítica social. Aunque por ese mismo motivo se podrían incluir La aldea maldita (1942) de Florián Rey, y Forja de almas (1943), de Eusebio Fernández Ardavín, ambos de directores falangistas, que establecen el marco en el que el Movimiento perdería el control de la cinematografía.

Pero, en mi opinión, en este primer grupo se deberían, de todos modos, distinguir aquellas con rasgos filofalangistas de las propiamente falangistas.

Las filofalangistas serían aquellas películas que tendrían algunos motivos temáticos o simbólicos afines al ideal de Falange, gracias a la influencia que el Movimiento tenía en ese momento en la dirección del aparato cinematográfico, pero que coinciden a la vez y mayormente con los postulados franquistas, puesto que, como el caso de El crucero Baleares o Rojo y negro, aquellas que no encajaban con el ideal (o el gusto de los militares) quedaron orilladas. Las películas propiamente falangistas serían, por lo demás, aquellas cuya identidad ideológica es muy patente ya sea por su intención o sus características internas. Por ello, películas como ¡Harka! (1941), ¡A mí la legión! (1942), Sin novedad en el Alcázar (1940), El crucero Baleares (1941) y Porque te vi llorar (1941), se podrían calificar de filofalangistas. Y, únicamente, en este periodo, solo podría considerarse falangista Frente de Madrid (1939) y Rojo y negro (1942).

Después de todo, las dos primeras películas antes citadas son de temáticas puramente castrenses, afines al espíritu marcial que impregnaba la victoria en la contienda y que casaba con el ideal falangista. Pero hay incidir en que sus protagonistas no son falangistas. De hecho, es una apología u homenaje a los militares africanistas, los oficiales que rodeaban a Franco y al mismo dictador.

En las dos siguientes nos encontramos con dos capítulos importantes sobre la Guerra Civil pero la presencia de falangistas es casi anecdótica (al menos en Sin novedad en el Alcázar ${ }^{21}$ ) y su único rasgo falangista auténtico es la inclusión del himno Cara al sol en algunos momentos de ambos filmes. Pero el uso de este himno no fue más que un intento de imponer sus liturgias y no pueden calificarse estos filmes como nutridos directamente de su ideología ${ }^{22}$. Se trata, tan solo, de largometrajes bélicos de marcado acervo conservador y de un espíritu castrense que encajaban con el ambiente triunfal propiciado por la victoria. Su concepción vino más dada por recordar la Guerra Civil y subrayar quiénes fueron sus artífices, los militares, más que por educarnos o mostrar aspectos del proyecto falangista.

\footnotetext{
${ }^{20}$ Fernández Colorado, Luis, "Fortunato”, en Pérez Perucha, Julio (ed.), Antología crítica del cine español (19061995), Madrid, Cátedra, 1997, p. 137.

${ }^{21}$ Archivo General de la Administración (en adelante, AGA), Cultura, expediente de censura, 36/03170. Es más, la Comisión de Censura, el 3 de octubre de 1940, pidió que se suprimiese el "diálogo de los oficiales referente al apoyo moral prestado al Movimiento". Y un mes más tarde, el 8 de noviembre, pidió explícitamente incluir fondos musicales de los "himnos Nacional, Falange Española Tradicionalista, Oriamendi y de la Legión”. Estos cambios parecían mostrar, así, la necesidad de dar cohesión (aunque fuera solo a nivel musical) al franquismo, aunque no lo tuviera.

${ }^{22}$ Box, Zira, "Símbolos eternos de España”, en Michonneau, Stéphane y Xosé Manoel Núñez Seixas (eds.), Imaginarios y representaciones de España durante el Franquismo, Madrid, Casa de Velázquez, 2014, p. 15.
} 
En cuanto a Fortunato (1941), al igual que en los largometrajes posteriores, no cabe identificar rasgos netamente falangistas salvo en la interpretación que se realice de su temática, ya que es una crítica a la sociedad insolidaria, el clientelismo y la decadencia de la época republicana. La censura únicamente consideró que debía dejarse claro que la sociedad retratada era la anterior a la contienda aunque reflejaba más la gris posguerra ${ }^{23}$. Aunque la censura no siempre acertó con las intenciones ocultas de los directores, no hay muchos rasgos más que nos puedan ofrecer la impresión de que Delgado estuviese motivado por cuestiones falangistas sino conservadoras. Ya que, además, se trataba de una adaptación de una obra de teatro de los hermanos Álvarez Quintero de principios de siglo y en modo alguno pertenecía a ningún autor falangista. E igual que otros artistas al servicio del régimen, pretendían mostrar o denunciar las vergüenzas de la sociedad democrática-liberal frente a la franquista. Y el cine de Delgado asumía los planteamientos franquistas en el cine.

Así mismo, otra de las películas consideradas falangistas, Porque te vi llorar (1941), de Juan de Orduña ${ }^{24}$, uno de los más destacados directores del franquismo, retrata los efectos devastadores de la Guerra Civil (y el "terror rojo") en una familia noble, cuya hija, María Victoria, es violada por un miliciano. Producto de dicha violación tendrá un hijo que cuidará con celo y mimo. Sin embargo, acabada la contienda, aparecerá un joven electricista, José, que insinúa que es el padre de la criatura, lo que provocará la angustia de la protagonista. Pero, claro, José ha sido, en realidad, un abnegado combatiente del bando nacional. Aparte de los valores de honor y lealtad y sus características religiosas, el interclasismo, la relación final entre una marquesa y un electricista, es el único rasgo falangista que se ofrece en el filme ${ }^{25}$.

En la misma línea se puede incluir el remake que hizo Florián Rey de La aldea maldita (1942). Aunque Florián Rey sería uno de los más destacados directores de la época republicana, en trabajos como La aldea maldita (1930), Nobleza baturra (1935) o Morena Clara (1936), en 1935 se afiliaría a la Falange. Tras la guerra prosiguió su carrera como director pero no tendría ya el mismo éxito ${ }^{26}$.

La nueva versión de La aldea maldita era muy reveladora de la nueva visión que se quería ofrecer del campo español. Las relaciones, frente al original, se vuelven más idealizadas. Y se presenta la Guerra Civil como un castigo divino.

Así, mientras los sectores católicos recibieron el tratamiento de la historia como “inmoral”27, al aparecer las relaciones adúlteras de una mujer, los falangistas en Primer Plano ${ }^{28}$ la llenaron de elogios por representar el "nuevo amanecer de las haces falangistas". Era más que

\footnotetext{
${ }^{23}$ AGA, Cultura, Caja 21/4456.

${ }^{24}$ AGA, Cultura, Caja 36/03182. Fue declarada totalmente apta, 5 de diciembre de 1941, aunque únicamente para mayores de 14 años.

${ }^{25}$ Gubern, Román, 1936-1939: La guerra de España en la pantalla, Madrid, Filmoteca Española, 1986, pp. 9394. Así, su unión deshace el antagonismo de la lucha de clases y las reconcilia acabando con dicha contradicción. ${ }^{26}$ García Carrión, Marta, Sin cinematografía no hay nación. Drama e identidad nacional española en la obra de Florián Rey, Zaragoza, Diputación de Zaragoza, 2007.

${ }^{27}$ Recalde Iglesias, Marta, "La lucha entre..." op. cit., p. 321.

${ }^{28}$ Giménez Caballero, Ernesto, "Significado nacional de La aldea maldita", en Primer Plano, 18 de abril de 1943.
} 
evidente que se confrontaban dos maneras de entender el cine, revelando de forma amortiguada una confrontación entre el falangista y el católico pero más que por una cuestión ideológica lo era por un aspecto de índole ética y moral.

En ese sentido, Florián Rey mostraba a las claras la domesticación del "buen" falangista al régimen al no mostrar el campo empobrecido como en la primera versión, dotándolo de un sentido menos realista, perdiendo su propia credibilidad artística.

Centrándonos en las dos películas en el que los falangistas aparecen en la pantalla de forma destacada nos encontramos con la mencionada Frente de Madrid (1939), de Edgar Neville, inspirada en el mismo libro homónimo del director ${ }^{29}$.

El filme cuenta la tragedia de Javier Navarro, un falangista destinado al frente universitario de Madrid. Se le encomienda la misión de atravesar las líneas republicanas y contactar con el jefe de la quinta columna de la ciudad. Y aprovecha para visitar a su prometida. El filme no deja de ser una suerte de hechos pocos creíbles y falsificados, con un Madrid lleno de fascistas infiltrados y de extranjeros caricaturizados, en el que la pareja protagonista se sacrifica en aras de su ideal patriótico.

Falange, aquí, está sobrerrepresentada, pero no es una película que tuviera mucho recorrido por su aparente final conciliador. Se trataría de otra rareza, abalada por el hecho de que fuera producida en la Italia fascista, frente al cine bélico más estimado, donde los militares son los auténticos protagonistas de las hazañas bélicas.

Pero si hay una película falangista por antonomasia esta fue, sin duda, Rojo y negro (1942), de Carlos Arévalo. Si la revisión de La aldea maldita no gustó al catolicismo, Rojo y negro iba a convertirse en una película maldita porque estuvo a punto de desparecer (como sí sucedió con El crucero Baleares) y su historia estuvo teñida de muchas leyendas ${ }^{30}$. Pero lo que quedó claro es que si Raza fue el "filme-manifiesto del franquismo" 31 , Rojo y negro lo fue de los falangistas y acabó por simbolizar, en realidad, claramente su derrota política.

Arévalo irrumpió en el panorama de cine con Harka! (1941), muy bien recibida. Él mismo fue quintacolumnista durante la guerra y vio cómo su padre y su hermano falangista fueron fusilados $^{32}$. Por lo tanto, Rojo y negro era un homenaje a sus seres queridos. El argumento no difiere mucho de los planteamientos manidos del cine del régimen, salvo que la protagonista, Luisa, es una mujer falangista, siendo su novio Miguel, comunista. Arévalo lleva a cabo un retrato del Madrid rojo, de la persecución de los falangistas, de la violencia contra las derechas y del espíritu cruel de los enemigos de la patria..., pero todo ello lo aderezó con una construcción

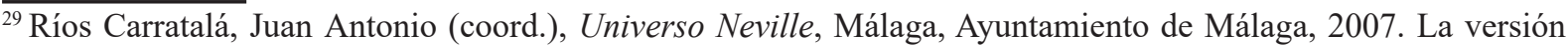
que se conserva es la italiana, Carmen fra $i$ Rossi, porque la española está perdida. El equipo de rodaje fue prácticamente el mismo salvo que el protagonista de la versión italiana fue Fosco Giachetti y en la española Rafael Rivelles.

${ }^{30}$ Elena, Alberto, “¿Quién prohibió Rojo y Negro?”, en Secuencias, 7 (1997), pp. 61-78. Nadie prohibió la película.

${ }^{31}$ Gubern, Román, "Raza”, en Pérez Perucha, Julio (ed.), Antología ... op. cit., p. 140.

${ }^{32}$ Rios Carratalá, Juan Antonio, El enigma de Carlos Arévalo. Alicante, Biblioteca Virtual Miguel de Cervantes, 2008
} 
cinematográfica audaz y compleja, recordando y tomando escenas del director ruso Eisenstein. Incluso, hay una mención simbólica al "ausente", a José Antonio, en unas imágenes en las que se muestra como la unidad falangista frente a los rojos es lo que arrastra al Movimiento Nacional hacia la victoria ${ }^{33}$. Estos elementos transgresores, a nivel visual, a los que se añadía una mirada en la que el protagonismo se depositaba en la heroica actitud de una mujer falangista, no gustaron en los sectores militares que, entonces, pretendían capitalizar todo el éxito de la victoria en la guerra ${ }^{34}$.

Frente al cine anteriormente mencionado en el que Falange añadía ciertos elementos coyunturales (la música o los ideales), su representación de un "espíritu de cruzada" 35 tan poco triunfal (la protagonista muere y no resucita como en Raza) derivó en que no obtuviera los parabienes del régimen y, finalmente, la productora decidiera retirarla de forma silenciosa de cartel hasta olvidarse casi por completo. Aunque la película fue un exponente más de la “cristalización de los mitos nacionales"36, retratando los males de la República, la demonización de los comunistas, la exaltación patriótica y el impulso del nacionalcatolicismo, su visión no era la que se quería establecer. El cine falangista solo fue un fallido "embrión”, tal y como lo califica José Luis Castro ${ }^{37}$. Apartado, como hemos visto, a partir de 1942 de algunos de los puestos más importantes del Nuevo Estado, el partido quedó al servicio de Franco y el perfil falangista del cine nacional perdió, prontamente, su influencia sustituido por los criterios más católicos. Luis Mariano González considera que "franquismo y fascismo son inseparables, especialmente en los duros años de la posguerra" 38 .

Así y todo, a la vista está que mostraron ciertas idiosincrasias diferenciadoras recogidas en el cine. Mientras que para el franquismo el fascismo era un elemento cohesionador, puntual, que casaba con sus intereses unificadores, el fascismo vio prontamente que sus anhelos de ser algo más se quedaron frustrados. Sometido políticamente al Caudillo e ideológicamente a un régimen autoritario y pragmático a la vez, que supo contener no solo la revolución falangista sino cualquier desviación a los principios ortodoxos que se postulaban desde el conservadurismo más tradicionalista.

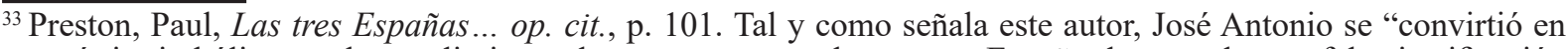
un mártir simbólico, y el cumplimiento de sus supuestos planes para España dotaron de una falsa justificación prácticamente cada acto del Caudillo". Fue, por tanto, muy útil para el régimen mantener el ideal falangista aunque vaciado de significado.

${ }^{34}$ Alzola Cerero, Pablo, "Vanguardia cinematográfica y disensión política en Rojo y Negro", en Film-Historia online, 1 (2017), pp. 39-52.

${ }^{35}$ Sanz Ferreruela, Fernando, "La idea de cruzada en el cine del primer franquismo", en García Cuetos, María Pilar et al. (coords.), Historia, restauración y reconstrucción monumental en la posguerra española, Madrid, Adaba Editores, 2012, pp. 407-435

${ }^{36}$ Sánchez-Biosca, Vicente, Cine y Guerra Civil española. Del mito a la memoria, Madrid, Alianza Editorial, 2006, p. 41.

${ }^{37}$ Castro de Paz, José Luis, Un cinema ... op. cit., p. 52.

${ }^{38}$ González González, Luis Mariano, Fascismo, Kitsch y cine histórica español, Cuenca, Ediciones Universidad de Castilla-La Mancha, 2009, p. 233.
} 
Después de todo, "cualquier conflicto entre las familias del régimen podía resolverse invocando la guerra y su legado traumático" ${ }^{39}$, como se comprobará más adelante, tras el polémico traslado de los restos de José Antonio al Valle de los Caídos. Y, en el peor de los casos, la Falange le debía completa fidelidad y "obediencia incondicional" ${ }^{40}$ al Caudillo. Pues, tal y como señala y sentencia Rodríguez Jiménez, "el partido estaba al entero servicio de Franco"41.

\section{Segunda etapa (1942-1975)}

Para finales de 1942, el rumbo de la Segunda Guerra Mundial había cambiado ostensiblemente. Las potencias del Eje (Alemania, Italia y Japón) habían perdido la iniciativa en los diferentes frentes de batalla. Y el régimen de Franco, con una hábil maniobra, se fue alejando de ellas. Por consiguiente, Falange empezó a perder el control que hasta ese momento sostenía de la cinematografía, los demás medios y la educación, pasando a ocuparlo la Iglesia. El franquismo mostraría, a partir de aquí, su interés por acercarse al bloque occidental. Y su anticomunismo y su tradicional catolicismo fueron los que, a la postre, le ayudarían a romper su aislamiento internacional ${ }^{42}$.

Cesado Serrano Suñer de sus cargos, la Falange perdió su preeminencia en la dirección cinematográfica. Esta derrota moral se evidencia en la reacción institucional tras el estreno de Forja de almas (1943), del falangista Eusebio Fernández Ardavín.

La película retrata la biografía del fundador de las escuelas Ave María, el padre Andrés Manjón (1846-1923). Para su rodaje, Fernández Ardavín contó con la colaboración de la Sección Femenina. Pero no gustó nada que en ella se escenificaran los batallones infantiles que creó el mencionado sacerdote, al considerar que se podían identificar con las escuadras falangistas. Tal recelo llevó a que ni el Ministerio de Educación ni la Iglesia la vieran con buenos ojos al notar en ella presentes más los valores revolucionares de la Falange que del catolicismo ${ }^{43}$.

Para esta segunda etapa, en la que cabría incluir el anterior filme, el historiador Kepa Sojo considera que las siguientes películas serían falangistas en relación a sus temáticas y estilos, añadiendo a esta lista Surcos (1951) y Bienvenido Míster Marshall (1953). Aunque también habrían de incluirse por otros motivos Ronda española (1951), de Ladislao Vajda, Embajadores en el infierno (1956), de José María Forqué, La fiel infantería (1959), de Pedro Lazaga, y La paz

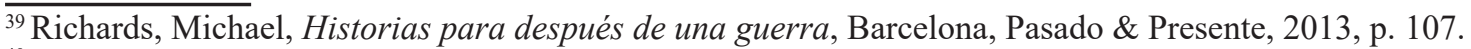

${ }^{40}$ Richmond, Kathleen, Las mujeres ... op. cit., p. 23.

${ }^{41}$ Rodríguez Jiménez, José Luis, Historia de Falange Española y de las JONS, Madrid, Alianza Editorial, 2000, p. 488.

${ }^{42}$ Cazorla Sánchez, Antonio, Las políticas... op. cit., pp. 64-65.

${ }^{43}$ AGA, Cultura, Caja 36/03194. Aun así, la Comisión de Censura aprobaría, el 28 de abril de 1943, de forma íntegra la cinta, sin cortes, siendo clasificada como tolerada para menores de 16 años.
} 
empieza nunca (1960), de León Klimovsky, estos últimos por el hecho de que los protagonistas de sus tramas son personajes de la Sección Femenina o falangistas.

A partir de 1950 fue evidente la transfiguración del régimen al acercarse a las potencias Occidentales y borrar la simbología fascista (pensemos en que se reestrenó Raza con cambios en los diálogos y se cortaron algunas escenas).

La primera película a tener en cuenta en este nuevo marco es, sin duda, Surcos (1951), cuyo director fue el falangista Nieves Conde.

Aunque un año antes había rodado una de las más emblemáticas y exitosas películas religiosas de la década, Balarrasa (1950), Surcos era muy distinta. Plantea los problemas de adaptación de las gentes del campo a la gran ciudad, en este caso, Madrid. En este retrato (influido por el neorrealismo) se radiografía no un marco idealizado sino crudo, desnudo, en el que se habla del crimen, la prostitución, el estraperlo, el desempleo, la miseria social y moral y, claro está, la delincuencia. La unidad familiar se ve destruida por estos perversos ingredientes sociales y, finalmente, tras las pésimas vicisitudes sufridas se ven obligados a retornar al campo.

El tono amargo y desgarrador lo convierte en un retrato esencial para conocer a la sociedad española pero no fue, por eso mismo, tan bien recibido por el régimen ${ }^{44}$. Después de todo, la trama coincidía en un contexto en donde empezaba a hacerse notar con fuerza cierto descontento urbano, tras producirse altercados en Barcelona, intentos de huelga general en Vizcaya y Guipúzcoa, sumado al amargor de antiguos falangistas por un movimiento emigratorio a las ciudades que los ideólogos más ortodoxos pretendían restringir, ante el temor al despoblamiento de la meseta ${ }^{45}$.

El filme fue auspiciado por José María García Escudero, primer director general de cinematografía y teatro, que le otorgaría con polémica la calificación de Interés Nacional ${ }^{46}$, aunque se vería obligado a rectificar. Así, para Óscar Ortego, "Surcos supone la culminación de un proceso de intentar interpretar la realidad de la España de los años 40 y 50 desde la perspectiva de una mentalidad falangista" 47 , puesto que consideraban que el campo era el fundamento esencial de la identidad española y la gran ciudad un lugar de decadencia y vicio. El mismo Nieves Conde reconocería años más tarde que sí había algo de ella de su "añeja y desilusionada ideología"48. Pero fue una gota en el desierto que en modo alguno ayudó a recuperar el valor crítico de la Falange.

\footnotetext{
${ }^{44}$ Guerra Gómez, Amparo, "Las heridas sociales de la paz. Clases y escenarios sociales de la postguerra en Surco", en Historia y Comunicación Social, 6 (2001), pp. 232-237. Tras haberse alterado convenientemente el final pudo pasar la censura.

${ }^{45}$ Juliá, Santos, "Madrid, capital del Estado (1833-1993)", en Juliá, Santos et al., Madrid, Historia de una capital, Madrid, Alianza Editorial, 1994, pp. 253-469.

${ }^{46}$ AGA, Cultura, Caja 36/3410. En la nota dirigida a la prensa para indicar por qué se había otorgado la máxima categoría se puede leer: "La película Surcos significa indudablemente un valor excepcional en nuestra cinematografía, por sus cualidades artísticas y técnicas y el modo de presentar el hondo problema social que en ella se plantea, que la haćen creedora al tal citado galardón”. Si bien, no todos pensaron lo mismo.

${ }^{47}$ Ortego Martínez, Óscar, "Cine, realismo..."op. cit., p. 404.

${ }^{48}$ Castro, José Luis y Julio Pérez Perucha, "Conversación con José Antonio Nieves Conde”, en Castro, José Luis y Julio Pérez Perucha (eds.), Tragedia e ironía: el cine de Nieves, Orense, Festival de Cine Independiente, 2003, pp. $137-152$
} 
Nieves Conde no volvió a realizar otro filme de tales características. Pero ese mismo interés por la situación de atraso del campo Sojo estima que se puede incluir en Bienvenido Míster Marshall (1953), aunque ni el director ni las intenciones (una aguda burla contra el régimen ${ }^{49}$ ) parecen del todo confirmarlo. La única clave para considerarla así es que fue producida por Uninci, de la que formaban parte los hermanos falangistas Joaquín y Alberto Reig, lo cual sí podía refrendar dicha hipótesis.

Pero no es algo que señale específicamente Alicia Salvador Marañón en su trabajo sobre la productora, quien indica que su objetivo fue, a partir de 1952, "la de hacer un cine de calidad, con la mayor dosis de compromiso político" ${ }^{50}$, eso sí, dentro de los límites que establecía el régimen. Convirtiéndose, de este modo, en un referente del sector "disidente" del régimen (cercano al PCE). Con lo que no podemos considerar que la película de Berlanga pueda ser considerada falangista ${ }^{51}$.

En contraste, ese mismo año se rodaría Ronda española (1951), del prolífico director húngaro Ladislao Vajda ${ }^{52}$, autor de Marcelino pan y vino (1955). En este contexto de apertura, la Sección Femenina, la cual "conservó sus estructuras, ideología y programa originales hasta el final del régimen de Franco" ${ }^{53}$, se iba a convertir en el mejor embajador de España al otro lado del Atlántico a través de sus grupos de bailes y danzas. Tuvo tanto éxito que este grupo se dedicó a recorrer otros lugares en un proselitismo tanto cultural como político, ayudando a mejorar la imagen de España en el exterior. En 1948, ya habían realizado actividades promocionadas en la Argentina de Perón, el único gobierno que defendió a España en la ONU, y que le había ayudado económicamente en los peores momentos de la autarquía.

A tal fin, en 1950, se reestrenaría la película Raza bajo el título Espíritu de una Raza, en el que se borrarían, por razones obvias, los aspectos fascistas de la misma, incluida la música del Cara al Sol que sí se podía escuchar en el filme original, incidiendo en su carácter anticomunista ante el nuevo contexto internacional de la Guerra Fría, donde la España de Franco quería mostrar sus credenciales como único país que había derrotado al comunismo. Esto nos muestra la capacidad de adaptación (dentro de ciertos límites, por supuesto) ideológica que caracterizó al franquismo a lo largo de su existencia (sobre todo, desprendiéndose de sus aspectos fascistas) ${ }^{54}$.

Ronda española relata las aventuras y desventuras de un grupo de jóvenes entusiastas chicas de la Sección Femenina que se embarcan, en Cádiz, en el buque Monte Albertia, con

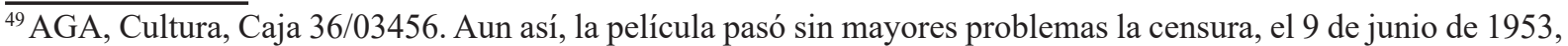
con la categoría de para todos los públicos.

${ }^{50}$ Salvador Marañón, Alicia, De ;Bienvenido Mr. Marshall! a Viridiana, Madrid, EGEDA, 2006, p. 658.

${ }^{51}$ Ibídem, pp. 155-221. El guión estaba firmado por Juan Antonio Bardem, Luis García Berlanga y Miguel Mihura, ninguno de ellos destacará, precisamente, por sus simpatías falangistas.

${ }_{52}^{52}$ Lunas, Francisco, Ladislao Vajda. El húngaro errante, Valladolid, SEMINCI, 1997.

${ }^{53}$ Richmond, Kathleen, Las mujeres... op. cit., p. 24.

${ }^{54}$ Gubern, Román, Raza: El ensueño del general Franco, Madrid, Ediciones 99, 1977; Caparrós, José María, El cine político visto después del franquismo, Barcelona, Dopesa, 1978; Berthier, Nancy, "Raza, de José Luis Sáenz de Heredia: una película acontecimiento", en Sánchez-Biosca, Vicente (coord.), España en armas: el cine de la guerra civil española, Valencia, Diputación de Valencia, 2007, pp. 53-62; Crusells, Magí, "Franco, un dictador de película: nuevas aportaciones a la raza", en Camarero, Gloria (coord.), Vidas de cine, el biopic como género cinematográfico, Madrid, T\&B Editores, 2011, pp. 239-284
} 
el fin de recorrer distintos países (como Perú, Chile, Argentina, Colombia, Panamá y otros del mar Caribe) para representar bailes regionales ${ }^{55}$. Su intención no es otra que recordar sus raíces a los emigrantes españoles que residen allí (

Pero como todo largometraje al servicio del régimen la historia tiene otros aspectos más propagandísticos. Lanza un mensaje de (falsa) reconciliación nacional (reconociendo los efectos negativos de la Guerra Civil) pero solo para mostrar el interés por recuperar a quienes fueron "engañados" por los comunistas y acabaron traicionando a su patria. Aunque no deja de ser un filme al servicio del régimen realizado para publicitar la españolidad en el exterior, refleja la importancia de la Sección Femenina al servicio del franquismo a la hora de educar en sus valores. De hecho, servía como un modelo que busca definir las virtudes femeninas españolas desde proverbiales aspectos psicológicos (obedientes, sensibles, bondadosas, alegres, amistosas y valientes, etc.) y, por supuesto, religiosos para representar a la "auténtica" España ${ }^{56}$.

Todo ello, en su relación con América, dando cuenta de la importancia de la Hispanidad (emulando al viejo imperio español $)^{57}$, un concepto muy falangista que, por supuesto, venía aderezado con la dosis justa de discurso anticomunista.

En suma, Ronda española mostraba que a estas alturas el discurso falangista y el franquista eran inseparables y que habían encontrado un modelo de encaje razonable en donde Falange-Sección Femenina se integraba como una fórmula más dentro del régimen. Además de facilitar la vertebración de la unidad española a través de la recuperación de una cultura popular regionalista (casi residual en algunos lugares), ensamblando tal pluralidad en un marco cultural común: España ${ }^{58}$.

La ideología falangista se configuraba, únicamente aquí, como parte de la cultura del régimen, pero ya hacía tiempo sin sus aspectos fascistas ni su concepción revolucionaria. Se presentaba desde un ideal femenino (que no feminista), en estas mujeres que se desarrollaban plenamente, a nivel educativo, cultural y personal hasta un límite, claro, sin desafiar la autoridad masculina, y representando (falsamente) las distintas clases de una sociedad cohesionada y $\operatorname{armonizada~}^{59}$. De todos modos, cabe destacar, en lo positivo, que gracias al impulso de la labor de los grupos de Coros y Danzas por América Latina se organizó el Congreso Femenino Hispanoamericano (1951), que daría lugar a un grupo de trabajo que determinaría que, en 1958, se reformara el Código Civil (nada menos que el de 1889) consiguiendo reparar algunas

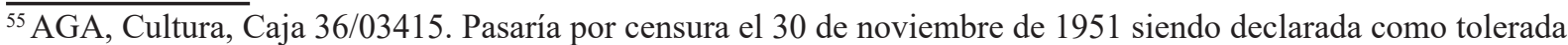
para menores y calificada como de categoría $1^{\circ}$ A y declarada de Interés Nacional por su "valor excepcional" para la cinematografía española y sus "cualidades artísticas y técnicas". Si bien, algunos de la junta consideraron que era una historia muy convencional y que no cobra verdadera sustancia hasta la aparición del exiliado rojo, Pablo. ${ }^{56}$ Amador Carretero, Pilar, "La mujer..." op. cit., pp. 108-119.

${ }^{57}$ García Cárcel, Ricardo, La herencia del pasado. Las memorias históricas de España, Barcelona, Círculo de Lectores, 2012, p. 565.

${ }^{58}$ Box, Zira, “Anverso y reverso de la nación: el discurso de la antiespañolada durante los primeros años 40", en Hispania, 249 (2015), p. 250.

${ }^{59}$ Preston, Paul, Las tres Españas... op. cit., pp. 143-176. Sobre un agudo retrato de la figura de Pilar Primo de Rivera artífice de que la Sección Femenina cobrara tanta relevancia en el seno del régimen.
} 
discriminaciones que sufrían las mujeres en la España de Franco ${ }^{60}$. No fueron, ni mucho menos, los logros alcanzados durante la Segunda República sobre los derechos de la mujer ${ }^{61}$, pero sí mostraban que el franquismo no podía detener el tiempo y que la apertura al exterior suponía cambios en el seno de la propia sociedad española.

Pero retornemos al cine bélico porque la Guerra Civil española siempre fue, sin duda, un elemento central en el imaginario franquista, a pesar de que ya abundara o destacara menos. $\mathrm{Y}$ aquí es donde vuelve a reaparecer Falange, en un contexto muy diferente a la época anterior (desarrollismo y apertura al exterior) pero, claro, "sin salirse de los principios ideológicos del Movimiento $^{62}$, en filmes como Embajadores en el infierno (1956), La fiel infantería (1959) o en La paz empieza nunca (1960), mostrando ese encaje forzado de las distintas familias del régimen, tan necesario para seguir enfatizando su pugna contra el comunismo, la legitimidad en la guerra y que la sociedad española no olvidara los sacrificios realizados.

Las dos últimas películas, en concreto, parecen nacer de un contexto muy particular, tras el polémico traslado de los restos de José Antonio, que reposaban en la cripta real de El Escorial, "como vínculo simbólico entre el falangismo y las glorias imperiales" ${ }^{6}$, al recién inaugurado Valle de los Caídos (31 de marzo de 1959). Muchos falangistas (incluida Pilar Primo de Rivera) lo entendieron como un rechazo a las ideas del "Ausente" por parte del régimen. Parece curiosa la coincidencia de que, fruto de este homenaje a la guerra, se produjeran a continuación dos películas cuyos protagonistas eran (o debían ser) falangistas, algo poco común en el cine. Por eso, se podría considerar que esta era una sutil estrategia para acallar ese malestar y recordar la aportación de Falange a la contienda y su plena integración en el franquismo.

Esto se iba a vislumbrar, en La fiel infantería (1959) de Pedro Lazaga o La paz empieza nunca (1960), de León Klimovsky.

Lazaga se convertiría en uno de los directores más comerciales del momento, y se uniría a un tardío intento de revitalizar el cine de la Guerra Civil. Antiguo combatiente republicano que acabaría redimiéndose luchando en la División Azul, firmaría otras películas sobre la contienda como La patrulla (1954), El frente infinito (1956), y Torrepartida (1956), además de algunas comedias ligeras como Muchachas de azul (1956), Ana dice sí (1958) o Trampa para Catalina $(1961)^{64}$

La trama de La fiel infantería (1959) se inspiraba en la novela homónima de Rafael García Serrano que ganó el Premio Nacional de Literatura José Antonio Primo de Rivera en 1943. La obra, ilustrativamente, correría pareja al devenir de Falange en esos años, ya que

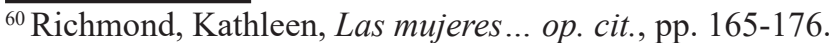

${ }^{61}$ Domingo, Carmen, Con voz y voto. Las mujeres y la política en España (1931-1945), Barcelona, Lumen, 2004.

${ }^{62}$ Torreiro, Casimiro, “¿Una dictadura liberal? (1962-1969)”, en Gubern, Román et al., Historia del cine ... op. cit., pp. 298.

${ }^{63}$ Richmond, Kathleen, Las mujeres... op. cit., p. 185.

${ }^{64}$ Crusells, Magí, La Guerra Civil española: cine y propaganda, Barcelona, Ariel, 2000, p. 192; Monterde, José Enrique, "El cine..." op. cit., p. 267
} 
sería prohibida hasta 1958 cuando se reimprimió y fue adaptada al cine ${ }^{65}$. La película pretendía ser un retrato "imparcial" de la contienda, aunque privilegiando el punto de vista del bando nacional. La referencia a Falange es puntual (solo se menciona de pasada al Movimiento una vez), borrándose todos los rasgos ideológicos presentes en la novela. De tal forma que la trama resulta ñoña. Es, ante todo, un homenaje a los combatientes de la guerra, aunque en un marcado acervo conservador. Y se incide más en las relaciones personales y los amoríos, que en la valoración y significado de la contienda, quedándose esta como una guerra más.

Curiosamente, por su sentido patriótico y político fue declarada de Interés Nacional. Si bien, no todos los censores pensaron de ella de forma tan elogiosa ${ }^{66}$.

Otra novela sería, del mismo modo, llevada al cine: La paz empieza nunca, de Emilio Romero, que ganaría el Premio Planeta de 1957, con muy distinto fin y sería también calificada de Interés Nacional ${ }^{67}$. En ella se relatan las vivencias de López, un joven falangista, desde las postrimerías de la Segunda República hasta 1952, cuando logra destruir al maquis asturiano. La trama, con añadidos por parte de la censura, pues no deja de ser una "historia oficial" del régimen, nos cuenta las vicisitudes hasta el tiempo presente de la filmación en que a López le corresponde convertirse en el modelo del abnegado español que lucha por la patria frente al denostado y corrosivo comunismo.

El filme era de encargo y recayó en el director internacional Klimovsky ${ }^{68}$. Pero aunque quiso darle una visión diferente a la historia, y la presentaba como una denuncia contra el fanatismo, lo cierto es que tanto la Junta de Censura como el propio autor de la obra lo impidieron. La Guerra Civil no dejaba de ser para ellos, debido a todos sus rigores y sacrificios, una lucha contra un detestable enemigo: los rojos.

Por supuesto saldrá airoso de la prueba y lanza, así mismo, un mensaje de advertencia frente a los incautos que creen que la paz se ha conseguido. La Falange encarna, por tanto, el ideal vigilante aunque identificado con el franquismo.

La otra película a destacar, antes señalada, sería Embajadores en el infierno (1956), que trataría la participación de falangistas (y otros españoles) en la campaña de Rusia (1941-1944), a favor de la Alemania nazi. El director sufriría presiones y acoso de exdivisionarios falangistas durante su rodaje, ante el temor de que no ofreciera una mirada adecuada de su experiencia. La película tuvo, a pesar de todo, una muy buena acogida de crítica y público, salvo por la prensa falangista (en Arriba, Solidaridad Nacional y Primer Plano), precisamente, por omitir

\footnotetext{
${ }^{65}$ Mata Induráin, Carlos, "La guerra civil y la ideología falangista en La fiel infantería de R. García Serrano", en Anthropos, 148 (1993), pp. 83-87. Sobre un análisis de la novela.

${ }^{66}$ AGA, Cultura, Caja 36/03745. La película fue autorizada para su exhibición por la censura el 21 de enero de 1960, catalogada para todos los públicos. En uno de los informes se señala que durante el primer tramo el filme "adolece de lentitud y reiteración". Y encuentra que se echa a faltar explicar el "porqué de la guerra". También hubo voces más severas considerando que "carece de calidad dramática (y por tanto de emoción), pero posee una gran calidad documental, ambiental y literaria". Y otro destaca que "la Falange y el Requeté brillan por su ausencia", y que tampoco se es muy riguroso con la descripción de la vida militar.

${ }^{67}$ AGA, Cultura, Caja 36/03799.

${ }^{68}$ Pérez Gómez, Ángel y José Luis Martínez Montalbán, Cine español 1951/1978. Diccionario de directores, Bilbao, Ediciones Mensajero, 1978, p. 172.
} 
cualquier referencia a su ideología en la trama, algo que para ellos era lo que, sin duda, revelaba el carácter diferenciador de su unidad militar, de ahí su nombre, División Azul ${ }^{69}$.

A partir de ahí, las referencias a la Falange, por su ideario o por su presencia, acaban por desvanecerse. La inminente transición y la descomposición del régimen dieron pie a que el cine propagandístico desapareciera. En cambio, sí empezaría a brillar con más fuerza un cine disidente y crítico, perdiéndole el miedo a la censura. Cabe, por ello, destacar, el tratamiento que se hizo en La prima Angélica (1974), de Carlos Saura ${ }^{70}$, de un personaje secundario falangista, que trajo su polémica, al mostrar enyesado su brazo derecho como si lo estuviera ridículamente alzando, lo que implicaba una burla ${ }^{71}$. Además de ser presentado como un personaje, brutal, despótico y tiránico. Falange era, a estas alturas, no solo un proyecto obsoleto, reaccionario y minoritario, sino que, irónicamente, era representado como la oscura sombra de la dictadura.

\section{A modo de conclusión}

La Falange no consiguió constituir nunca un cine propio puro, se dieron puntuales excepciones como Frente de Madrid (aunque producida en Italia, no lo olvidemos) o Rojo y Negro, en la primera etapa, y Surcos, en la segunda, pues el resto de filmes podemos calificarlos como filofalangistas, cada uno de ellos respondiendo al contexto en el que se desarrollaron. Todo lo cual deja bien claro que la Falange siempre estuvo sometida a las reglas impuestas desde el franquismo, incluso, en su "época dorada", vio cómo su película estrella Rojo y Negro nunca pudo encontrar un verdadero hueco en el panorama cinematográfico nacional, al ser arrinconada. A partir de 1942, ese control ideológico franquista se intensificó. Solo rarezas como Surcos pudieron darse como una auténtica crítica a la imagen bucólica que el régimen quería presentar de la Nueva España feliz. El fracaso de construir un cine fascista fue reflejo de su sometimiento político, ideológico e institucional, a las necesidades de una dictadura que no solo había ganado la guerra sino que también imponía su paz.

De las 18 películas analizadas solo en tres de ellas nos encontramos con personajes falangistas protagonistas como son Frente de Madrid, Rojo y Negro, Ronda española y La paz

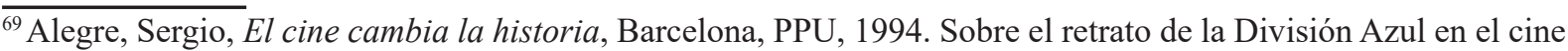
español; Alegre, Sergio, "Embajadores en el infierno", en Santiago de Pablo (coord.), La historia a través del cine, Bilbao, Universidad del País Vasco, 2000, pp. 81-96.

${ }^{70}$ AGA, Cultura, Caja 36/04245. Claro que eso no le evitó que fuese autorizada únicamente para mayores de 18 años. A pesar de todo obtendría una subvención económica, al ser considerada de Interés especial, tras ser revisada la petición (ya que fue denegada en primera instancia) debido a su reconocimiento internacional. Tras haber estado en la Semana de cine español, en Praga, se le dedicó una retrospectiva a la obra de Saura y el premio a la Mejor Dirección en el Festival internacional de Cannes, además del Premio Especial del Jurado antes señalado.

${ }^{71}$ Galán, Diego, Venturas y desventuras de la prima Angélica, Valencia, Fernando Torres Editor, 1974; Crusells, Magí, La Guerra Civil... op. cit., pp. 204-205.
} 
empieza nunca. Y se comprueba con ellas el modo en el que se fue domesticando a Falange, puesto que si la primera es una fallida reivindicación del espíritu de José Antonio las otras dos nos desvelan el sometimiento de Falange al ideario del régimen. De las demás, debemos pensar que Sin novedad en el Alcázar, ¡Harka!, la desaparecida El crucero Baleares, Raza, ¡A mí la legión! y La aldea maldita, son hijas de su tiempo. Por lo que sus aspectos falangistas vienen marcados por el elemento musical, temático y ritual, no tanto porque lo fueran explícitamente.

El caso más evidente es el de Raza pues se impostaron en ella rasgos del falangista dominante, de los que se deshicieron sin pudor en la versión de 1950.

Por sus intenciones, Forja de almas y Surcos sí parecen recoger parte del espíritu falangista, pero ya hemos podido comprobar que de carácter singular, más temático que ideológico (ya que no se ofrecen alusiones directas a su ideario) y no dejan de mostrarse como oasis en el desierto, más por la iniciativa personal de los directores que por constituir, como lo sería el cine disidente, una corriente propia, al margen de las directrices dominantes impuestas o bendecidas por la dictadura.

Así mismo, las películas Embajadores en el infierno, La fiel infantería y La prima Angélica nos muestran, respectivamente, una el conveniente borrado que se hizo del protagonismo de Falange en la guerra (donde el franquismo había logrado su legitimidad) y la otra su total descrédito postrero, una humillante demostración de su falta ya de influencia y poder.

Y, finalmente, incidir en que ni en Fortunato, ni en Porque te vi llorar ni en Bienvenido Mister Marshall se aprecian rasgos falangistas, salvo tangencialmente.

En suma, en modo alguno se puede hablar de un cine falangista como entidad cinematográfica propia, viéndose muy prontamente sometido a las directrices de un régimen que no iba a permitir (nunca) que nadie cuestionase el protagonismo de los militares en la guerra, el control conservador y eclesiástico del discurso ni, por supuesto, la cohesión que le ofrecía el ideario franquista dominante.

Los falangistas acabaron muy pronto "disueltos" en el imaginario cinematográfico convirtiéndose en meros referentes (casuales, en su mayoría) de una dictadura que tras la victoria solo se había preocupado de forma simbólica y muy pragmática a reforzar sus fortalezas, arrinconando o disponiendo un equilibrio para que ninguna de las familias del régimen fuese más importante que otra. En ese sentido, el cine es muy revelador de esta "domesticación" del proyecto falangista en la España de Franco. 
Anexo: Filmografía básica en relación o vinculada a Falange durante el franquismo

\begin{tabular}{|c|c|c|c|c|}
\hline Películas (18) & $\begin{array}{c}\text { Director } \\
\text { (Nacionalidad e } \\
\text { ideología) }\end{array}$ & $\begin{array}{l}\text { Personajes } \\
\text { principales }\end{array}$ & Temática & Intención \\
\hline $\begin{array}{l}\text { Frente de Madrid } \\
\text { (1939) }\end{array}$ & $\begin{array}{l}\text { Española } \\
\text { Falangista }\end{array}$ & Falangista & Guerra Civil & Apología de Falange \\
\hline $\begin{array}{l}\text { Sin novedad en el } \\
\text { Alcázar (1940), Au- } \\
\text { gusto Genina }\end{array}$ & $\begin{array}{l}\text { Italiano } \\
\text { Fascista }\end{array}$ & Militares & Guerra Civil & Apología bando nacional \\
\hline $\begin{array}{l}\text { ¡Harka! (1941), de } \\
\text { Carlos Arévalo }\end{array}$ & $\begin{array}{c}\text { Español } \\
\text { Falangista }\end{array}$ & Militares & Colonial & $\begin{array}{c}\text { Apología militarismo } \\
\text { africanista }\end{array}$ \\
\hline $\begin{array}{l}\text { Fortunato } \\
\text { (1941), Fernando } \\
\text { Delgado }\end{array}$ & $\begin{array}{c}\text { Español } \\
\text { Franquista }\end{array}$ & Gente corriente & Social & $\begin{array}{c}\text { Crítica social (Segunda } \\
\text { República) }\end{array}$ \\
\hline $\begin{array}{l}\text { El crucero Baleares } \\
(1941), \text { Enrique del } \\
\text { Campo }\end{array}$ & $\begin{array}{c}\text { Mejicano } \\
\text { Conservador }\end{array}$ & Militares & Guerra Civil & Apología bando nacional \\
\hline $\begin{array}{l}\text { Porque te vi llorar } \\
\text { (1941), Juan de Or- } \\
\text { duña }\end{array}$ & $\begin{array}{c}\text { Español } \\
\text { Franquista }\end{array}$ & $\begin{array}{l}\text { Nobles y mili- } \\
\text { tares }\end{array}$ & Guerra Civil & Apología bando nacional \\
\hline $\begin{array}{l}\text { Raza (1941), José } \\
\text { Luís Sáenz de Here- } \\
\text { dia }\end{array}$ & $\begin{array}{l}\text { Español } \\
\text { Franquista }\end{array}$ & Militares & Guerra Civil & Franquismo \\
\hline $\begin{array}{l}\text { ¡A mí la legión! } \\
\text { (1942), Juan de Or- } \\
\text { duña }\end{array}$ & $\begin{array}{l}\text { Español } \\
\text { Franquista }\end{array}$ & Militares & Colonial & $\begin{array}{c}\text { Apología militarismo } \\
\text { africanista }\end{array}$ \\
\hline $\begin{array}{l}\text { Rojo y negro (1942) } \\
\text { Carlos Arévalo }\end{array}$ & $\begin{array}{c}\text { Español } \\
\text { Falangista }\end{array}$ & $\begin{array}{c}\text { Sección feme- } \\
\text { nina } \\
\end{array}$ & Guerra Civil & Apología de Falange \\
\hline $\begin{array}{l}\text { La aldea maldita } \\
(1942), \quad \text { Florián } \\
\text { Rey }\end{array}$ & $\begin{array}{c}\text { Español } \\
\text { Falangista }\end{array}$ & Gente corriente & Rural & Drama rural \\
\hline $\begin{array}{l}\text { Forja de almas } \\
\text { (1943), Eusebio Fer- } \\
\text { nández Ardavín }\end{array}$ & $\begin{array}{l}\text { Español } \\
\text { Falangista }\end{array}$ & $\begin{array}{c}\text { Gente Corrien- } \\
\text { te }\end{array}$ & Religioso & $\begin{array}{l}\text { Religión pilar de la socie- } \\
\text { dad española }\end{array}$ \\
\hline $\begin{array}{l}\text { Surcos (1951) José } \\
\text { Antonio Nieves } \\
\text { Conde }\end{array}$ & $\begin{array}{c}\text { Español } \\
\text { Falangista }\end{array}$ & Gente corriente & $\begin{array}{l}\text { Sociedad fran- } \\
\text { quista }\end{array}$ & $\begin{array}{l}\text { Crítica a modernidad y } \\
\text { crisis de valores }\end{array}$ \\
\hline $\begin{array}{l}\text { Ronda española } \\
(1951), \text { Ladislao Va- } \\
\text { jda }\end{array}$ & $\begin{array}{c}\text { Húngaro } \\
\text { Conservador }\end{array}$ & $\begin{array}{l}\text { Sección Feme- } \\
\text { nina }\end{array}$ & $\begin{array}{l}\text { Cultura espa- } \\
\text { ñola }\end{array}$ & $\begin{array}{c}\text { Apología del nacionalis- } \\
\text { mo español }\end{array}$ \\
\hline
\end{tabular}




\begin{tabular}{|c|c|c|c|c|}
\hline Películas (18) & $\begin{array}{c}\text { Director } \\
\text { (Nacionalidad e } \\
\text { ideología) }\end{array}$ & $\begin{array}{l}\text { Personajes } \\
\text { principales }\end{array}$ & Temática & Intención \\
\hline $\begin{array}{ll}\text { Bienvenido } & \text { Míster } \\
\text { Marshall } & \text { (1953), } \\
\text { Luís García } & \text { Berlan- } \\
\text { ga } & \end{array}$ & $\begin{array}{c}\text { Español } \\
\text { Comunista }\end{array}$ & Gente corriente & $\begin{array}{l}\text { Sociedad fran- } \\
\text { quista }\end{array}$ & Crítica social \\
\hline $\begin{array}{l}\text { Embajadores en el } \\
\text { infierno (1956), de } \\
\text { José María Forqué }\end{array}$ & Español & $\begin{array}{c}\text { Falangistas y } \\
\text { militares }\end{array}$ & División Azul & Anticomunismo \\
\hline $\begin{array}{l}\text { La fiel infantería } \\
\text { (1959), Pedro } \\
\text { Lazaga. }\end{array}$ & $\begin{array}{c}\text { Español } \\
\text { Franquista }\end{array}$ & Militares & Guerra Civil & Apología franquismo \\
\hline $\begin{array}{l}\text { La paz empieza nun- } \\
\text { ca (1960), León Kli- } \\
\text { movsky }\end{array}$ & $\begin{array}{l}\text { Argentino } \\
\text { Conservador }\end{array}$ & Falangistas & Guerra Civil & Apología franquismo \\
\hline $\begin{array}{l}\text { La prima Angélica } \\
\text { (1974), Carlos Saura }\end{array}$ & $\begin{array}{c}\text { Español } \\
\text { Antifranquista }\end{array}$ & Sociedad & $\begin{array}{l}\text { Sociedad fran- } \\
\text { quista }\end{array}$ & Antifranquismo \\
\hline
\end{tabular}

